\title{
DEVELOPMENT OF ELECTRONIC COMMERCE
}

\author{
Katarzyna WITCZYŃSKA \\ Wroclaw University, Institute of Economic Sciences; katarzyna.witczynska@uwr.edu.wroc.pl, \\ ORCID: 0000-0002-8021-3967
}

Purpose: The paper presents the issues related to the development of electronic commerce. Design/methodology/approach: The study used world-bank reports from statista portal.

Findings: The purpose of this article is to present the development of electronic commerce and investment climate of Poland on the example of Lower Silesia created by economic, social, political and legal-administrative conditions. The economic conditions inform the foreign investor about the condition of the economy of the country receiving the investment. Functioning types of e-business and basic business models used in e-commerce were also presented. Furthermore, they were characterized by payment methods used in online sales. Based on a chart developed on the basis of statistical data analysis of consumer-preferred online payment methods was also made.

Originality/value: The publication presents the results of research conducted on the basis of statista international portal.

Keywords: electronic commerce, direct investment, international investment climate, COVID-19.

Category of the paper: Research paper.

\section{Introduction}

The coronavirus (COVID-19) continues to sweep across, it is taking an ever-increasing toll on public health, as well as numerous other industries and sectors. From travel and tourism to finance and construction - almost every aspect of economy has been affected by the global pandemic. One industry that has seen particularly noticeable changes over the past few months is e-commerce. As most countries have issued stay-at-home orders in an attempt to slow the spread of the disease, many people are now self-isolating while turning to technology for work, education, communication, and shopping. 


\section{History of electronic commerce development}

The electronic commerce market (so-called e-commerce) is currently the most dynamically developing branch of commerce. The term e-business was first used in 1995 by IBM (International Business Machines Corporation). According to one of the simplest definitions proposed by S. Pangsy-Kania, e-business is a type of business that is run with the use of ICT solutions, including primarily web applications, as well as automatic delivery or exchange of information and business data (Pangsy-Kania, 2012). According to authors such as A. Hartman, J. Sifonis and J. Kadora, electronic business refers to all projects implemented via the Internet, mainly tactical and strategic ones, which transform business relationships such as business-toconsumer (business - clients), business-to-business (business - business) or intra-business (business connections). These authors added that e-business is a new source of efficiency, speed and innovation of enterprises and the functioning of new ways to create value in the organization (Hartman, J. Sifonis, J. Kador, 2001). The OECD definition indicates that this trade is a business ran through the network, the WTO definition states that it covers various means of production or marketing, and the WCO definition says that it supports data traffic between computer systems of different enterprises. Among the events immediately preceding the emergence of e-commerce were:

- removing in 1991 commercial restrictions imposed by NSFNET (National Science Foundation NET) regarding the use of the Internet by individual users and then the creation, with the participation of IBM, Merit Network Inc. and MCI Communication Corp., of infrastructure which made it possible to make commercial Internet connections;

- creation in 1993 of one of the first web browsers - Mosaic, thanks to which virtually anyone could navigate around network and use its resources;

- finalizing in 1995 the contract for the sale of ANS to America Online, thanks to which all Internet infrastructure remained so far only at the disposal of the public sector, and then it was passed to the private sector which began to play the most important role in the further development of the Internet;

- commencing commercial operations on the Internet in 1995 by companies such as Amazon (the world's largest online store that offers books, music and movies), Dell (producer of computer equipment) or eBay (portal with online auctions), which caused mass development of e-commerce and gradual dissemination of its individual forms and models among more companies (Tian, Stewart 2006). 


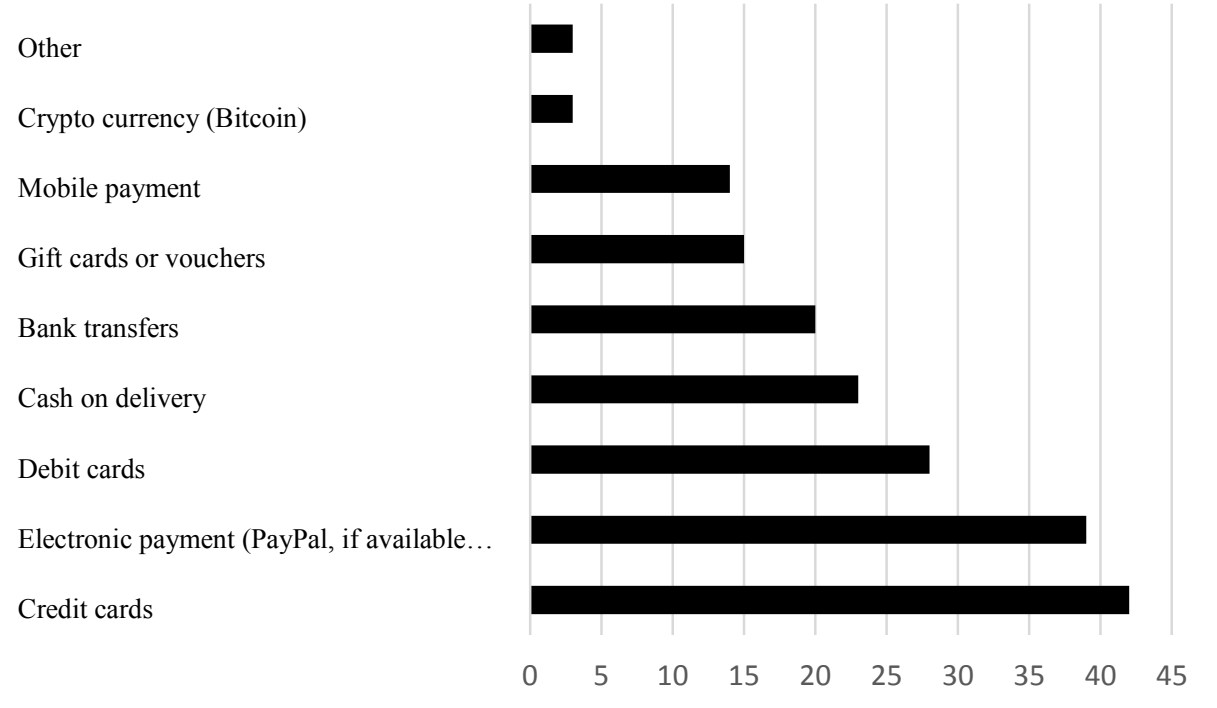

Figure 1. Preferred payment methods of online shoppers worldwide as of March 2017, [source: own study based on https://www.statista.com/statistics/508988/preferred-payment-methods-of-onlineshoppers-worldwide/, 2020].

\section{Examples of international electronic commerce}

Electronic commerce involves entering into commercial transactions and selling products through various means and electronic devices, such as the Internet, telephone or fax that are currently the most popular ones. International e-commerce consists of three basic entities: consumers, enterprises and administration. Due to the nature of the relationship between these entities, several types of e-business have developed. The basic relationships between e-commerce entities include (Combe, 2006):

- $\mathrm{C} 2 \mathrm{C}$ (customer-to-customer) - it refers to transactions between consumers that are carried out, for example, as part of the operation of auction sites,

- $\mathrm{C} 2 \mathrm{~B}$ (customer-to-business) - includes transactions between consumers and enterprises, with consumers as their initiators, where the goal is, for example, price comparison,

- $\mathrm{C} 2 \mathrm{G}$ (customer-to-government) - these are transactions between citizens and public administration that concern, for example, taxes,

- B2B (business to business) - this is a "classic" e-business and it includes implementation of business processes between two enterprises,

- $\mathrm{B} 2 \mathrm{C}$ (business-to-consumer or business-to-client) - this is a "classic" e-commerce and it includes transactions between businesses and consumers, 
- B2G (business-to-government) - it covers transactions between enterprises and public administration, such as public procurement or tenders,

- $\mathrm{G} 2 \mathrm{C}$ (government-to-citizen) - it concerns the flow of administrative information from offices to citizens,

- G2B (government-to-business) - it covers the flow of economic information (customs documents, statistical data) from offices to companies

- G2G (government-to-government) - this is the cooperation between organs of public administration which coordinates internal processes.

Another typology regarding types of e-business divides them into:

- public services related to e.g. health care (medical e-consultation),

- electronic banking (online accounts),

- real estate management (e-files),

- financial services (e-broker),

- logistics services (free freight and vehicle exchanges),

- tourist services (electronic reservation systems),

- services integrated with a product (mobile telephony),

- e-work (e-recruitment)

Recent years have brought a sharp increase in e-commerce sales as shown in the figure below.

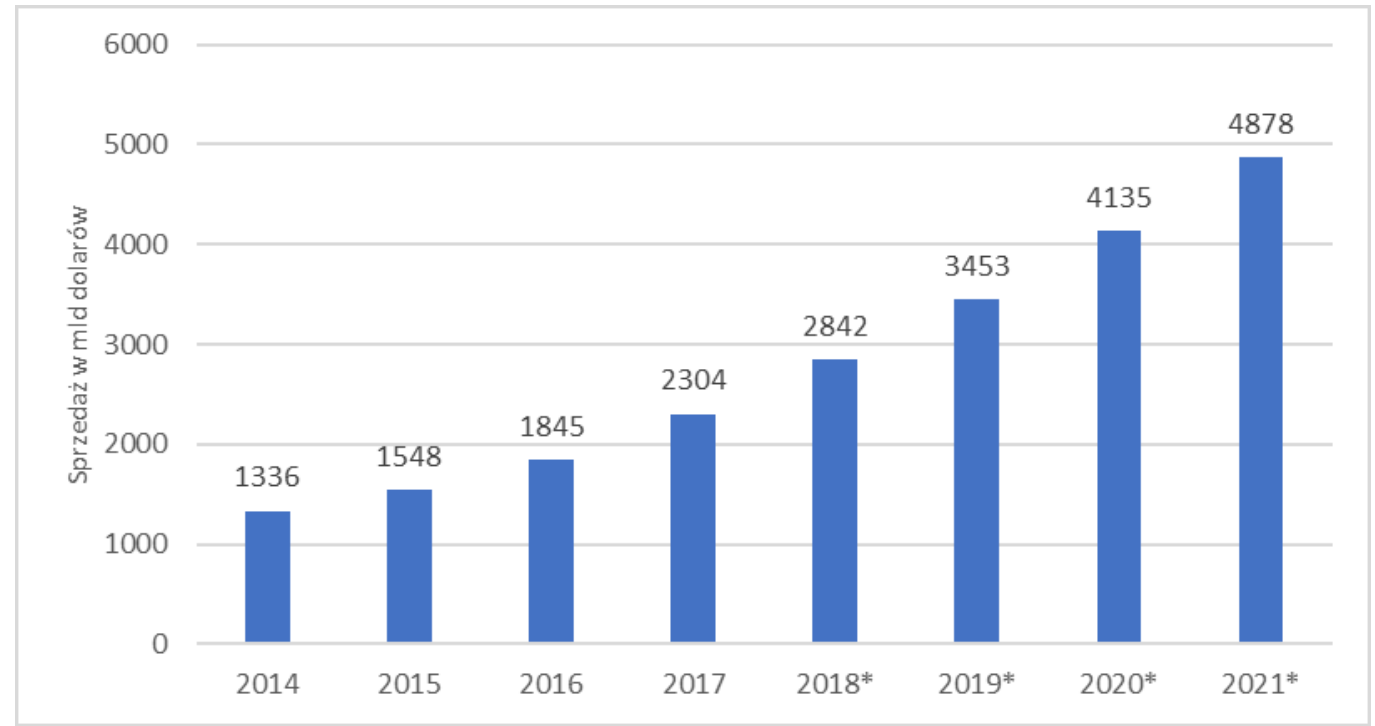

Figure 2. Sales of e-commerce worldwide from 2014 to 2021, [source: own study based on https://www.statista.com/statistics/508988/preferred-payment-methods-of-online-shoppersworldwide/, 2020] 


\section{Payment methods in electronic commerce}

Cash payments are a form of payment that is mainly intended for people who want to pay for online purchases but do not have a bank account or payment card. There are several ways to make a cash payment for a good or service purchased online, which include:

- payment on delivery (cash on delivery), which consists in the fact that we pay for the ordered goods or service to the delivery agent upon delivery. Then our payment is transferred, electronically, to the account or, optionally, to the indicated address, by postal order. Although this type of payment was until recently the most popular payment method (especially in Poland), it is usually unprofitable, as it involves high fees and after adding them it may turn out that it would be more profitable to buy goods in a stationary store;

- postal order, i.e. payment made at any post office, using a postal form, then sent to the recipient's address;

- a bank transfer, carried out at a bank branch which adds a commission for the transfer that was made in the bank. The amount of commission depends on the type of account and the bank from which the transfer is made;

- VIA - Moje Rachunki is a cash payment option at one of approx. 7,000 retail outlets in Poland, such as Carrefour, Kaufland, or PKN Orlen and Bliska gas stations;

- Small Bills is an option implemented in "Żabka" stores; it consists of paying bills whose total amount does not exceed PLN 500. A fee of around PLN 2 is added to the fees;

- UKASH vouchers are an international method of payment using vouchers previously purchased for cash, e.g. at a kiosk or gas station. In this case, the payer first purchases coupons of a selected value, and then redeems them in a store by entering a 19-digit coupon number at the time of purchase.

Online bank transfers are not much different from traditional transfers implemented in the bank branch. The main difference is only that the customers registered in online banking carry out all the activities themselves while in the case of traditional transfers they would be made with the help of a bank employee using the Internet network. A bank transfer guarantees customers secure use of funds because each transaction requires authentication (e.g. via SMS code) and approval by the account holder before making a purchase. Unfortunately, due to the fact that this is an "in advance" payment method, i.e. before receiving the ordered goods or services, it still raises the fear that the product will not be delivered or the seller will delay sending it. It is important, therefore, to approach this form of payment wisely and use it in a situation where we can be sure that the person who receives our money is trustworthy. Some time ago, to make such a transfer, the customer had to $\log$ in to his account and know the company account number usually given on the website of the online store, fill in the recipient's details himself, as well as the amount he intends to send. The intermediary systems for 
transaction processing are easy to use. The customer, using the payment system, is redirected to the automatically completed payment form. He does not have to worry that he will make a mistake when completing the account number and the money will go to a wrong recipient. Using payment systems requires the seller to have an individual account. There are many websites dealing with this type of activity. The most popular are:

- Przelewy24, which is owned by the Poznań company Dial-Com24 which is also the owner of the Tickets24.pl portal. The Przelewy24 system was established in 2004. Since then its popularity began to grow rapidly and more and more Internet sellers decided to use its services.

- PayU is a system belonging to the company with the same name, which is part of the Allegro Group.

What distinguishes this system from many others operating on this market is the fact that it is not intended to support e-businesses and online stores, but to handle individual transactions carried out by private individuals on the Internet.

The biggest advantage of the website is that you can make transactions without having an online bank account.

- PayPal, which is a definite pioneer of this type of payments. Especially in the US market it plays a very important role, having hundreds of millions of customers. Its advantage is that its activity is not limited only to the Internet.

- DotPay is a website founded in 2000, belonging to the company DotPay S.A. It is a European company and the portal is available in nine different languages.

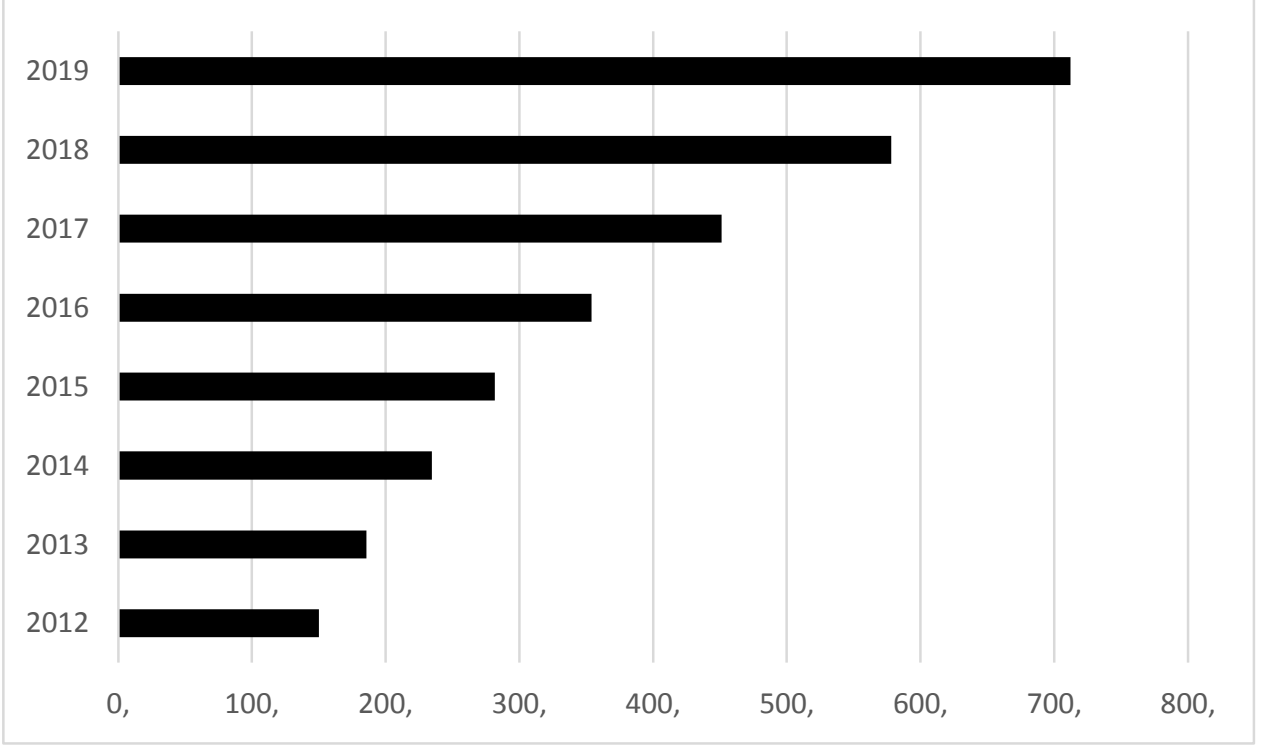

Figure 3. PayPal's annual payment volume from 2012 to 2019 (in billion U.S. dollars). Source: own study based on https://www.statista.com/statistics/508988/preferred-payment-methods-of-onlineshoppers-worldwide/, 2020. 


\section{Blik}

The Polish PSP payment standard says that in March 2020 BLIK users' activity increased the most in online stores selling electronics and household appliances. In this category, the increase compared to February is as much as 270 percent. Second place were household chemistry stores, where the increase in the number of transactions month to month is 216 percent. The third most-chosen category turned out to be online bookstores with an increase in the number of transactions by 85 percent.

\section{Consumer purchasing patterns under COVID-19 and electronic commerce}

COVID-19 contributes to growth of e-commerce. The global coronavirus pandemic is affecting consumer behaviour worldwide. In the week ending April 26, online traffic in the supermarket segment increased by 135 percent compared to the reference period in January and February 2020. In general, e-commerce sales have increased in recent years, which is a trend that was expected to continue through 2024. It is likely that this sector will see further increases due to COVID-19, as many people choose to stay at home and change their daily routines to avoid catching the airborne virus. As people spend longer stretches at home, consumers are purchasing more non-perishable food items, cleaning supplies, and home entertainment products. This is often done through online marketplaces, such as Walmart or Amazon. In contrast, there has been a decrease in spending in clothing and furniture stores, as most of these locations have been temporarily shut down to help prevent the spread of coronavirus. 


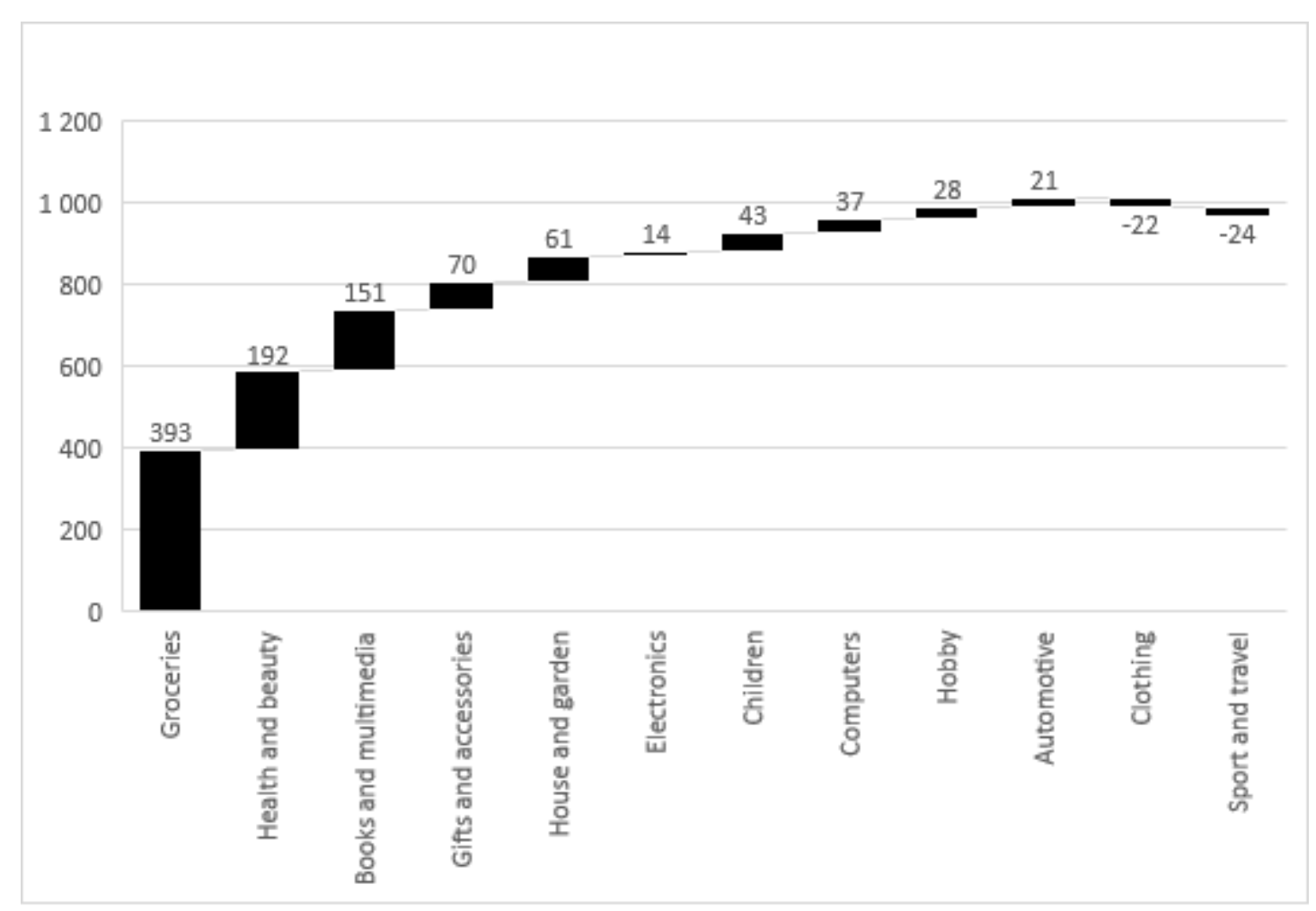

Figure 4. Growth in transactions number and sales value of orders in online stores due to the coronavirus (COVID-19) outbreak in Poland from February to March 2020, by category, [source: own study based on https://www.statista.com/statistics/508988/preferred-payment-methods-of-online-shoppersworldwide/, 2020].

\section{Summary}

The e-commerce market will undoubtedly continue to grow, resulting in an increasing number of enterprises that are very likely to decide to start operations under it. The growing share of e-commerce in total commerce will increase the belief of potential customers that online shopping is easy and secure. And as more and more people are acquiring confidence to buy online, the value of the average shopping basket will increase. It will be a slow but systematic process. The consumers will be increasingly interested in more expensive products, gaining the courage to buy them and thus the e-commerce market will undoubtedly continue to grow, causing that more and more companies are likely to start operating under it. 


\section{References}

1. Combe, C. (2006). Introduction to e-business, management and strategy. AmsterdamBoston-Heidelberg-London-New York-Oxford-Paris: Routledge.

2. Hartman, A. (2001). Strategie sukcesu w gospodarce internetowej. Sprawdzone metody organizacji przedsięwzięć e-biznesowych. Warszawa: Wydawnictwo K.E. Liber.

3. https://www.statista.com/statistics.

4. Pangsy, S. (2012). Rola innowacji w sektorze usług. In: M. Olszański, K. Piech (eds.), E-biznes - innowacje w ustugach. Teoria, praktyka, przykłady. Warszawa: Polska Agencja Rozwoju Przedsiębiorczości.

5. Tian, Y. (2006). History of E-Commerce. In: M. Khosrow-Pour (ed.), Encyclopedia of E-commerce, E-government, and Mobile Commerce. London: Idea Group Publishing. 